International Journal of Medical Sciences

ISSN 1449-1907 www.medsci.org 2006 3(2):41-46

Review

(C)2006 Ivyspring International Publisher. All rights reserved

\title{
Epidemiology of Hepatitis C Virus (HCV) Infection
}

\author{
Theodore Sy, M. Mazen Jamal
}

Division of Gastroenterology, University of California, Irvine, CA 92868, USA

Corresponding address: M. Mazen Jamal, University of California Irvine, 101 The City Drive, Orange, CA 92868, USA.

Received: 2005.12.30; Accepted: 2006.03.23; Published: 2006.04.01

Hepatitis $C$ virus remains a large health care burden to the world. Incidence rates across the world fluctuate and are difficult to calculate given the asymptomatic, often latent nature of the disease prior to clinical presentation. Prevalence rates across the world have changed as well with more countries aware of transfusion-related hepatitis $\mathrm{C}$ and more and more evidence supporting intravenous drug use as the leading risk factor of spread of the virus. This article reviews current hepatitis $C$ virus prevalence and genotype data and examines the different risk factors associated with the virus.

Key words: Epidemiology, hepatitis C virus, blood transfusions, intravenous drug use

\section{Prevalence}

Hepatitis $\mathrm{C}$ virus (HCV) continues to be a major disease burden on the world. In 1999, the WHO estimated a worldwide prevalence of about $3 \%$ with the virus affecting 170 million people worldwide. [1] (Table 1). Generally, most studies of prevalence use blood donors to report the frequency of $\mathrm{HCV}$ usually by anti$\mathrm{HCV}$ antibodies and do not report follow-up $\mathrm{HCV}$ testing. Using blood donors as a prevalence source may underestimate the real prevalence of the virus because donors are generally a highly selected population. [2]

In the Third National Health and Nutrition Examination Survey (NHANESIII) from 1988 to 1994, an estimated HCV prevalence of 3.9 million people was found in the United States (US) with 2.7 million people found to have chronic infection with HCV (positive HCV RNA). Neither sex nor racial-ethnic group was found to be independently correlated with $\mathrm{HCV}$ infection. However, a majority of patients that were $\mathrm{HCV}$ positive were below the age of 50. [2]

Among Central and South America, a recent community based study in San Juan, Peurto Rico, showed that estimated prevalence of HCV in 2001-2002 was $6.3 \%$. [3] In Mexico, the prevalence reported was about $1.2 \%$. (4) Among blood donors in Chile and Brazil, prevalence of $\mathrm{HCV} \mathrm{Ab}$ was low - $0.3 \%, 1.14 \%$ respectively. [5,32]

In Europe, general prevalence of $\mathrm{HCV}$ is about $1 \%$ but varies among the different countries. [6] Prevalence of HCV antibody is $0.87 \%$ (1993-1994) in Belgium. [7] In the United Kingdom, at least 200,000 adults carry HCV. [8] In Northern Italy, prevalence of $\mathrm{HCV} \mathrm{Ab}$ was 3.2\%. [9] Three studies in Central and Southern Italy showed a higher rate of $\mathrm{HCV}(8.4 \%-22.4 \%)$, especially in the older population. [10-12] Among patients of general practitioners in Lyon, France, the prevalence of HCV was estimated to be $1.3 \%$, very similar to the French general population. [13] Within the Russian army, frequency of anti-HCV was $1.5 \%$ among servicemen and donors with increased prevalence in the North Caucasus, Far East and Siberia (3.1-3.8\%) compared to the Transbaikal region $(0.7 \%)$. [14] Low rates were found in Hungary (0.73\% of 15,864 blood donors.) [31]
Table 1: Hepatitis C estimated prevalence and number infected by WHO Region. Source: Weekly Epidemiological Record. $\mathrm{N}^{\circ}$ 49, 10 December 1999, WHO.

\begin{tabular}{|c|c|c|c|c|}
\hline WHO Region & $\begin{array}{c}\text { Total } \\
\text { Population } \\
\text { (Millions) }\end{array}$ & $\begin{array}{c}\text { Hepatitis C } \\
\text { prevalence } \\
\text { Rate } \%\end{array}$ & $\begin{array}{c}\text { Infected } \\
\text { Population } \\
\text { (Millions) }\end{array}$ & $\begin{array}{c}\text { Number-of } \\
\text { countries by } \\
\text { WHO Region } \\
\text { where data are } \\
\text { not available }\end{array}$ \\
\hline Africa & 602 & 5.3 & 31.9 & 12 \\
\hline Americas & 785 & 1.7 & 13.1 & 7 \\
\hline $\begin{array}{c}\text { Eastern } \\
\text { Mediterranean }\end{array}$ & 466 & 4.6 & 21.3 & 7 \\
\hline Europe & 858 & 1.03 & 8.9 & 19 \\
\hline South-East Asia & 1500 & 2.15 & 32.3 & 3 \\
\hline Western Pacific & 1600 & 3.9 & 62.2 & 11 \\
\hline Total & 5811 & 3.1 & 169.7 & 57 \\
\hline
\end{tabular}

Recently, HCV prevalence studies have come out of Pakistan in the Middle East. 751 out of 16,400 patients (4.57\%) were found to + HCV Ab from 1998-2002 with the largest age group from 41-50. [15] Among male blood donors in Karachi, Pakistan, the seroprevalence of HCV was $1.8 \%$ with a trend of increasing proportion of positive donors from 1998-2002. [16] There has been very high prevalence rates of HCV reported in Egypt in the past $(28 \%)$. [17] This was confirmed among 90 blood donors in Cairo, where $14.4 \%$ were anti-HCV positive by RIBA test. [18] Then $26.6 \%$ among 188 blood donors and $22 \%$ among 163 donors were positive with both studies done in Cairo. $[19,20]$ Rates were lower in Saudi Arabia $(1.8 \%)$ and Yemen $(2.1 \%)$. [33, 34]

Intermediate rates of $\mathrm{HCV}$ have been reported out of Asia. From 1995-2000, 0.49\% anti-HCV Ab were detected among 3,485,648 blood donors in Japan. [44] This was lower than the $0.98 \%$ our of $10,905,489$ blood donors reported in 1992. [21] In China, prevalence rates were generally low with rates around 1\% among donors in Beijing and Wuhan. [22, 23] However, rates may be higher in certain areas such as the Hubei province $(30.13 \%)$ and Inner Mongolia Autonomous Region $(31.86 \%)$. [24] Low rates have been found in Malaysia (around 1.6\%) and Singapore (0.54\%). [25.26] Higher rates of HCV have been found in Thailand (3.2-5.6\%). $[27,28]$ Within a smaller community of 103 residents in Sherpas, Nepal, only 1 person had a borderline reaction 
in 2004. [29] In New Delhi, India, $1.85 \%$ of blood donors were positive. [30]

There have been fewer studies out of Africa, but lower rates have been reported $-1.6 \%$ among blood donors in Ethiopia and $0.9 \%$ in Kenya. [35, 36]

The estimated prevalence in Australia has been recently reported as $2.3 \%$ with the virus affecting 210,000 people by 2001 . The $20-24$ year old age group had the highest prevalence with strong majority of the infected population below the age of 50. [37]

\section{Risk Factors}

\section{Intravenous drug use}

Transmission of Hepatitis C virus has been strongly associated with intravenous and percutaneous drug and needle use. Reported cases of hepatitis C from intravenous drug use is on the rise in the US. In a study of injection drug users in Baltimore, Maryland from 1988 to $1996,30.3 \%$ of participants developed anti-HCV antibodies with most in the first 2 years of the study. [38] Among 310 drug users in Antwerp and Limburg in Belgium, $71 \%$ and $46 \%$ had anti-HCV antibody, respectively. [39] The Hepatitis C European Network for C-operative Research (HENCORE) group reported a prevalence of hepatitis C of $80 \%$ among intravenous drug users (IVDU). [6] In the District Buner study in Pakistan, all 751 anti-HCV patients had a history of injections. [15] 90\% of IVDU in Chang Rai, Thailand were positive for HCV. [27] 36.6\% of randomly selected IVDU in Sydney, Australia and 74\% of IVDU in Melbourne, Australia were HCV positive. [42,43] A recent study in London, England took 428 intravenous drug users below the age of 30 and found that $44 \%$ had antibodies to hepatitis C compared to $4 \%$ with HIV. This came out to an incidence of 41.8 cases per 100 person years of antibody to HCV. [40]

The importance of intravenous drug use can not be overemphasized. The prevalence of HCV among people who acquired HIV through intravenous drug use reaches $90 \%$. [41] Co-infection of the two viruses can make treatment all the more difficult. Most countries with a young population of $\mathrm{HCV}$ infection must deal with intravenous drug use as the leading cause for spread of the virus. Many of these intravenous drug users do not know they are infected. Screening of HCV and treatment of substance abuse are extremely important in this group.

\section{Blood Transfusions}

Transfusion of blood products has been a leading cause of transmission of $\mathrm{HCV}$; however, due to improved screening, transmission through transfusions has decreased in most developed countries. In Japan, incidence of post-transfusion non-A non-B hepatitis among those with less than 10 transfusions dropped from $4.9 \%$ (1988-Oct '89) to $1.9 \%$ (Nov'89-90) after screening with first-generation anti-HCV test was introduced. [45] In the US, incidence of post-transfusion hepatitis C dropped from $3.84 \%$ to $0.57 \%$ per patient $(0.03 \%$ per unit blood) after HCV screening was introduced in 1990. [46] In England, the frequency HCV infected donations dropped from 1 in 520,000 (1993-98) to 1 in 30 million (1999-2001) when donations were tested for HCV RNA. [47]

However, incidence of transfusion related hepatitis $\mathrm{C}$ is still higher in other areas of the world. In a study of
147 Chilean patients with chronic hepatitis C, the most common risk factor was blood transfusion in $54 \%$ versus just 5\% with IVDU. [48] A study was done in the largest blood bank in Santa Catarina, Brazil from 1991-2001 showing a significant drop in risk of acquiring $\mathrm{HCV}$, but the lowest risk of 1:13721 was still almost 10 times higher than that of developed countries. [49] Despite better screening for selecting blood donors, there remains a need for some kind of HCV screening laboratory test.

\section{Sexual activity}

The role of sexual activity in the transmission of $\mathrm{HCV}$ remains unclear. In the NHANESIII study, number of sexual partners (OR 2.54 for 2-49 partners) and age at first sexual intercourse (OR 2.94) had significant correlation with $\mathrm{HCV} \mathrm{Ab}$ and this has been confirmed in other studies. [2,3] Among 1257 non-IVDU in Baltimore at a STD clinic $9.7 \%$ were positive for $\mathrm{HCV}$. [50] One hypothesis is that many of the hepatitis $C$ patients may have injecting sexual partners. In one study, $15 \%$ of non IVDU women with an injecting partner had HCV. [51] More recently, a 10-year prospective follow-up study (8060 person-years) showed no evidence of sexual transmission among monogamous couples in Italy. [52] However, in a study among spouses in Egypt, it was estimated that wife to husband transmission was $34 \%$ and $10 \%$ among women with and without detectable HCV RNA. Husband to wife transmission was estimated at $3 \%$. Overall, $6 \%$ were estimated to have contracted $\mathrm{HCV}$ from their spouse. [53] One most remember however that the prevalence of $\mathrm{HCV}$ is much higher in Egypt and this study did not emphasize monogamous relationships and transmission between spouses can only be assumed to be sexual in nature. Also recently, there was lack of evidence found for sexual transmission of $\mathrm{HCV}$ among men who have sex with men in the prospective ongoing Omega Cohort Study in the US (2653 person-years of follow-up). [54] All of this new evidence supports that sexual transmission of $\mathrm{HCV}$ is still rare but for some reason is higher among those with high-risk sexual activity.

\section{Hemodialysis}

It has been well documented that dialysis patients have a higher rate of HCV infection. In the 90's much of the world reported anti-HCV prevalence rates of $10-50 \%$ among hemodialysis patients with lower rates in such places as Ireland (1.7\%). [55-60] Previously, rates in Europe were as high as 20-30\%. [6] A more recent report from Saudi Arabia showed a prevalence rate of $\mathrm{HCV}$ among hemodialysis patients to be $9.24 \%$ compared to $0.30 \%$ among blood donors. [61] In a tertiary-care hospital in Mexico City, Mexico, the rate of anti-HCV was $6.7 \%$ compared to the roughly $1.2 \%$ prevalence in the population of Mexico. [62] The rate of seroconversion among hemodialysis patients with no other risk factors has been reported 1.38-1.9\%/year. [63,64] These studies generally conclude that the transmission of the virus to hemodialysis patients is generally nosocomial with possible risk factors being failure to disinfect devices between patients, sharing of single-use vials for infusions, poor sterile technique, poor cleaning of dialysis machines, and poor distance between chairs. [65] 


\section{Special Populations}

The prevalence of HCV has been noted to be higher in other populations as well. Among kidney transplants, the prevalence was reported to be as high as 33.3\% in Italy with the frequency higher prior to $1990(50 \%)$ than after 1990 (27\%). [66] Obviously, most of these kidney transplant patients underwent dialysis as well.

The United States Veteran Affairs medical centers have also reported a higher prevalence of $\mathrm{HCV}$ than the general population with percentages as high as $35 \%$ in the VA Palo Alto system. [67] The most recent study among 20 centers reported an estimated prevalence of $5.4 \%$ with $78 \%$ reporting a risk factor of either transfusion or intravenous drug use. Seropositivity was also associated with tattoo use and incarceration in this study. [68]

There is also an increased prevalence of HCV also among prison inmates. One example is the Riverside county jail system where $25 \%$ adults incarcerated carried the virus while only $2 \%$ of the juvenile detention population carried HCV. [69] The juvenile detention population therefore provides a target for teaching and intervention since many of these juveniles acquire the virus early in their adult years.

\section{Genotypes of $\mathrm{HCV}$}

$\mathrm{HCV}$ is divided among six genotypes with numerous subtypes. These genotypes can differ up to $30 \%$ from each other in nucleotide sequence. Depending on the $\mathrm{HCV}$ genotype, length of treatment can differ. Genotype $1 \mathrm{~b}$ is less responsive to alpha-interferon therapy compared to genotypes 2 and 3 . It is therefore important to track the different genotypes of the HCV virus. In the NHANESIII study done in the US, 56.7\% were classified as $1 \mathrm{a}, 17 \%$ as $1 \mathrm{~b}, 3.5 \%$ as $2 \mathrm{a}, 11.4 \%$ as $2 \mathrm{~b}$, $7.4 \%$ as $3 a, 0.9 \%$ as $4,3.2 \%$ as type 6 . [2] $50 \%$ of all infections were by genotype 1 with a higher percentage of genotype 3 among the IVDU population in England. $[70,71]$ Genotype $1 \mathrm{~b}$ was the predominant genotype $(46 \%$ among blood donors) in Chile and was found in all infected patients with hepatocarcinoma in one study. [5] This same genotype was also found in $82 \%$ of 147 chronic hepatitis $C$ patients in Chile as well. [48] Genotype $1 \mathrm{~b}$ is also dominant in Japan. [72-74] In Beijing, China, of 63 HCV-RNA samples, $52 \%$ were genotype 2 and $29 \%$ type 3. [22] In Thailand, HCV 3a was the most common genotype at $50-60 \%$ with $1 \mathrm{a}, 1 \mathrm{~b}$, and 6 comprising the rest $(10-20 \%$ each). [27] Out of 90 patients in Estonia, $73.3 \%$ carried $1 b, 20 \%$ with $3 a$, and $6.7 \%$ with $2 a$. [75] Genotype 3 is most common on the Indian subcontinent while genotype 4 is the most common genotype in Africa and the Middle East. [76-80] Genotype 5 can be found in South Africa and as mentioned above, genotype 6 can be found in south-east Asia. [81,82]

\section{Prevention}

Primary prevention of hepatitis C should target reduction of transmission of the virus. Prevention should target those at risk of acquiring the virus and should involve providing education, risk reduction counseling, $\mathrm{HCV}$ screening and substance abuse treatment. In the US, the Centers for Disease Control (CDC) suggest screening for the follow population:

- Persons who ever injected illegal drugs, including those who injected once or a few times many years ago.
- Persons who received a blood transfusion or organ transplant before July 1992.

- Persons who received clotting factor concentrates before 1987.

- Persons who were ever on long-term dialysis.

- Children born to HCV-positive women.

- Healthcare, emergency medical, and public safety workers after needlesticks, sharps, or mucosal exposures to HCVpositive blood.

- Persons with evidence of chronic liver disease.

Extra attention should be given to populations in specific settings such as correctional institutions, drug treatment programs, programs for high risk youth, HIV counseling and testing sites, and STD clinics. In these settings, physicians should always screen for intravenous drug use. Unlike HIV, HCV is found in high concentrations in filters, spoons, and rinsing liquids that may be used in association with needle drug use. Patients should be counseled on contaminated equipment being a source of infection. Addiction care and counseling should be focused on with possible referrals for psychotherapy and detoxification. [83-85]

Prevention in healthcare setting should also take place by having better sterilization, safer injections, reducing opportunities for percutaneous exposures to blood. In developing countries, better screening for donors and blood screening should take place to reduce the number of transfusion related transmissions.

Once a patient is found to have hepatitis $C$, that patient needs to be counseled to reduce the risk of $\mathrm{HCV}$ transmission to others. The physician should also offer counseling on treatment, reducing alcohol usage and immunization with hepatitis A, hepatitis B, pneumococcal and influenza vaccines. HCV negative persons with ongoing risk factors also require counseling and immunization with hepatitis $\mathrm{A}$ and hepatitis B vaccines. [83-85]

Future research in this field will need to be continued. We will need to continue to evaluate the incidence of the virus third world countries as well as the transmissibility of the various genotypes. Better prevention, screening and treatment methods for Hepatitis $C$ virus all need to be elucidated.

\section{Conflict of interest}

The authors have declared that no conflict of interest exists.

\section{References}

1. WHO. Global surveillance and control of hepatitis C. Report of a WHO Consultation organized in collaboration with the Viral Hepatitis Prevention Board, Antwerp, Belgium. J Viral Hepat 1999;6:35-47

2. Alter MJ, Kruszon-Moran D, Nainan OV, McQuillan GM, Gao F, Moyer LA, Kaslow RA, Margolis HS. The prevalence of hepatitis C virus infection in the United States, 1988 through 1994. N Engl J Med 1999; 341:556-62

3. Perez CM, Suarez E, Torres EA, Roman K, Colon V. Seroprevalence of hepatitis $\mathrm{C}$ virus and associated risk behaviours: a populationbased study in San Juan, Puerto Rico. Int J Epidemiol. 2005; 34(3):593-9

4. Uribe M, Mendez-Sanchez N. Hepatitis C in Mexico. Rev Gastroenterol Mex. 2002; 67:S7-S8.

5. Munoz G, Velasco M, Thiers V, Hurtado C, Brahm J, Larrondo-Lillo M, Guglielmetti A, Smok G, Brechot C, Lamas E. Prevalence and genotypes of hepatitis $C$ virus in blood donors and in patients with 
chronic liver disease and hepatocarcinoma in a Chilean population. Rev Med Chil. 1998; 126(9):1035-42.

6. Touzet S, Kraemer L, Colin C, Pradat P, Lanoir D, Bailly F, Coppola RC, Sauleda S, Thursz MR, Tillmann H, Alberti A, Braconier JH, Esteban JI, Hadziyannis SJ, Manns MP, Saracco G, Thomas HC, Trepo C. Epidemiology of hepatitis $C$ virus infection in seven European Union countries: a critical analysis of the literature. HENCORE Group (Hepatitis C European Network for Cooperative Research). Eur J Gastroenterol Hepatol 2000; 12:667-678.

7. Van Damme P, Thyssen A, Van Loock F. Epidemiology of hepatitis C in Belgium: present and future. Acta Gastroenterol Belg 2002; 65: 78-79.

8. [Internet] Department of Health: UK. Hepatitis C strategy for England.

2002. http://www.doh.gov.uk/assetRoot/04/07/59/86/04075986.pdf

9. Bellentani $S$, Tiribelli $C$. The spectrum of liver disease in the general population: lesson from the Dionysos study. J Hepatol 2001; 35:5317.

10. Stroffolini T, Menchinelli M, Dambruoso V, Menniti Ippolito F, Costantino A, Rapicetta M, Lecce R, Taliani G. High prevalence of hepatitis $C$ virus infection in a small central Italian town: lack of evidence of parenteral exposure. Ital J Gastroenterol 1995; 27:235-8.

11. Raffaele A, Valenti M, Iovenitti M, Matani A, Bruno ML, Altobelli E, D'Alessandro A, Barnabei R, Leonardis B, Taglieri G. High prevalence of $\mathrm{HCV}$ infection among the general population in a rural area of central Italy. Eur J Epidemiol 2001; 17:41-6.

12. Maio G, d'Argenio P, Stroffolini T, Bozza A, Sacco L, Tosti ME, Intorcia M, Fossi E, d'Alessio G, Kondili LA, Rapicetta M, Mele A. Hepatitis $C$ virus infection and alanine transaminase levels in the general population: a survey in southern Italian town. J Hepatol 2000; 33:116-20.

13. Pradat $P$, et al. Prevalence of hepatitis $C$ infection among general practice patients in the Lyon area, France. Eur J Epidemiol. 2001;17(1):47-51.

14. Ogarkov PI, Malyshev VV, Tokmakov VS, Smirnov AV. Epidmiological features of virus hepatitis in the Russian army. Minerva Gastroenterol Dietol 2004; 50: 165-9.

15. Muhammad N, and Jan MA. Frequency of Hepatitis $C$ in Buner, NWFP. JCPSP 2005, 15 (1): 11-14.

16. Aktar S, Younus M, Adil S, Jafri SH, Hassan F. Hepatitis C virus infection in asymptomatic male volunteer blood donors in Karachi, Pakistan. J Viral Hepat. 2004; 11(6):527-35.

17. Saeed AA, al-Admawi AM, al-Rasheed A, Fairclough D, Bacchus R, Ring C, Garson J. Hepatitis C virus in Egyptian blood donors in Riyadh. Lancet 1991; 33: 359-60.

18. Darwish NM, et al. Hepatitis C virus infection in blood donors in Egypt. J Egypt Public Health Assoc. 1992; 67(3-4):223-36.

19. Bassily S, Hyams KC, Fouad RA, Samaan MD, Hibbs RG. A high risk of hepatitis $\mathrm{C}$ infection among Egyptian blood donors: the role of parenteral drug abuse. Am J Trop Med Hyg. 1995; 52(6):503-5.

20. Darwish MA, Raouf TA, Rushdy P, Constantine NT, Rao MR, Edelman R. Risk factors associated with a high seroprevalence of hepatitis $\mathrm{C}$ virus infection in Egyptian blood donors. Am J Trop Med Hyg. 1993; 49(4):440-7.

21. Yamaguchi K, Kiyokawa H, Machida J, Obayashi A, Nojiri N, Ueda S, Takatsuki K. Seroepidemiology of hepatitis $C$ virus infection in Japan and $\mathrm{HCV}$ infection in haemodialysis patients. FEMS Microbiol Rev 1994;14:253-258

22. Wang Y, Tao QM, Zhao HY, Tsuda F, Nagayama R, Yamamoto K, Tanaka T, Tokita H, Okamoto H, Miyakawa Y, et al. Hepatitis C virus RNA and antibodies among blood donors in Beijing. J Hepatol 1994;21: 634-640

23. Zhang YY, Hansson BG, Widell A, Nordenfelt E. Hepatitis C virus antibodies and hepatitis $C$ virus RNA in Chinese blood donors determined by ELISA, recombinant immunoblot assay and polymerase chain reaction. APMIS 1992;100:851-855

24. Tang S. Seroepidemiological study on hepatitis C virus infection among blood donors from various regions in China. Chin J Epidemiol 1993;14:271-274

25. Duraisamy G, Zuridah H, Ariffin MY. Prevalence of hepatitis C virus antibodies in blood donors in Malaysia. Med J Mal 1993;48: 313-316
26. Kuperan P, Choon AT, Ding SH, Lee G. Prevalence of antibodies to hepatitis $C$ virus in relation to surrogate markers in a blood donor population in Singapore. Southeast Asian J Trop Med Pub Health 1993;24(Suppl 1):127-129

27. Apichartpiyakul C, Apichartpiyakul N, Urwijitaroon Y, Gray J, Natpratan C, Katayama Y, Fujii M, Hotta H. Seroprevalence and subtype distribution of hepatitis $\mathrm{C}$ virus among blood donors and intravenous drug users in northern/ northeastern Thailand. Jpn J Infect Dis 1999;52:121-123

28. Songsivilai S, Jinathongthai S, Wongsena W, Tiangpitayakorn C, Dharakul T. High prevalence of hepatitis $\mathrm{C}$ infection among blood donors in northeastern Thailand. Am J Trop Med Hyg 1997;57:6669

29. Chiba H, Takezaki T, Neupani D, Kim J, Yoshida S, Mizoguchi E, Takeuchi J, Suzuki J, Tanaka Y, Ito K, Kitamura T, Kuriki K, Wakai K, Samejima K, Sonoda S, Tajima K. An epidemiological study of HBV, HCV, and HTLV-1 in Sherpas of Nepal. Asian Pac J Cancer Prev. 2004; 5(4):370-3.

30. Panigrahi AK, Panda SK, Dixit RK, Rao KV, Acharya SK, Dasarathy $S$, Nanu A. Magnitude of hepatitis $C$ virus infection in India: prevalence in healthy blood donors, acute and chronic liver diseases. J Med Virol 1997;51:167-174

31. Barna TK, Ozsvar Z, Szendrenyi V, Gal G. Hepatitis C virus antibody in the serum of blood donors. Orvosi Hetilap 1996; 137:507-511

32. Vasconcelos HC, Yoshida CF, Vanderborght BO, Schatzmayr HG Hepatitis $B$ and $C$ prevalences among blood donors in the south region of Brazil. Mem Inst Oswaldo Cruz 1994, 89: 503-507

33. Al-Faleh FZ, Ramia S, Arif M, Ayoola EA, al-Rashed RS, al-Jeffry M, Hossain A, el-Hazmi M. Profile of hepatitis C virus and the possible modes of transmission of the virus in the Gizan area of Saudi Arabia: a community-based study. Ann Trop Med Parasitol 1995;89:431-437

34. El Guneid AM, Gunaid AA, O'Neill AM, Zureikat NI, Coleman JC, Murray-Lyon IM. Prevalence of hepatitis B, C and D virus markers in Yemeni patients with chronic liver disease. J Med Virol 1993:40:330-333.

35. Frommel D, Tekle-Haimanot R, Berhe N, Aussel L, Verdier M, Preux PM, Denis F. A survey of antibodies to hepatitis $C$ virus in Ethiopia. Am J Trop Med Hyg 1993;49:435-439

36. Ilako FM, McLigeyo SO, Riyat MS, Lule GN, Okoth FA, Kaptich D. The prevalence of hepatitis $\mathrm{C}$ virus antibodies in renal patients, blood donors and patients with chronic liver disease in Kenya. East Afr Med J 1995;72:362-364

37. Amin J, Gidding H, Gilbert G, Backhouse J, Kaldor J, Dore G, Burgess M. Hepatitis C prevalence - a nationwide serosurvey. Commun Dis Intell. 2004; 28(4):517-21.

38. Villano SA, Vlahov D, Nelson KE, Lyles CM, Cohn S, Thomas DL. Incidence and risk factors for hepatitis $\mathrm{C}$ among injection drug users in Baltimore, Maryland. J Clin Microbiol 1997;35:3274-3277

39. Mathei C, Robaeys G, van Damme P, Buntinx F, Verrando R. Prevalence of hepatitis $C$ in drug users in Flanders: determinants and geographic differences. Epidemiol. Infection 2005; 133: 127-136

40. Judd A, Hickman M, Jones S, McDonald T, Parry JV, Stimson GV, Hall AJ. Incidence of hepatitis C virus and HIV among new injecting drug users in London: prospective cohort study. BMJ 2005; 330:24-5.

41. Sulkowski MS, Thomas DL. Hepatitis C in the HIV-infected person. Ann Intern Med 2003; 138:197-207.

42. Maher L, Chant K, Jalaludin B, Sargent P. Risk behaviours and antibody hepatitis $\mathrm{B}$ and $\mathrm{C}$ prevalence among injecting drug users in south-western Sydney, Australia. J Gastoenterology Hepatology. 2004; 19(10):1114-20.

43. Bradshaw CS, Pierce LI, Tabrizi SN, Fairley CK, Garland SM. Screening drug users for sexually transmitted infections and blood borne viruses using street outreach and self collected sampling. Sex Transm Infect. 2005; 81(1):53-8.

44. Tanaka J, Kumagai J, Katayama K, Komiya Y, Mizui M, Yamanaka R, Suzuki K, Miyakawa Y, Yoshizawa H. Sex- and age-specific carriers of hepatitis B and C viruses in Japan estimated by the prevalence in the 3,485,748 first-time blood donors during 19952000. Intervirology. 2004; 47(1):32-40. 
45. Japanese Red Cross Non-A Non-B Hepatitis Research Group. Effect of screening for hepatitis $C$ virus antibody and hepatitis B core antibody on incidence of post-transfusion hepatitis. Lancet 1991;338:1040-1041

46. Donahue JG, Munoz A, Ness PM, Brown DE Jr, Yawn DH, McAllister HA Jr, Reitz BA, Nelson KE. The declining risk of posttransfusion hepatitis C virus infection. N Engl J Med 1992;327:369373

47. Soldan K, Barbara JA, Ramsay ME, Hall AJ. Estimation of the risk of hepatitis B virus, hepatitis $C$ virus and human immunodeficiency virus infectious donations entering the blood supply in England, 1993-2001. Vox Sang. 2003; 84(4):274-86.

48. Soza, A, Arrese M, Gonzalez R, Alvarez M, Perez RM, Cortes P, Patillo A, Riquelme A, Riquelme A. Clinical and epidemiological features of 147 Chilean patients with chronic hepatitis C. Ann Hepatol. 2004; 3(4):146-51.

49. Kupek E. Transfusion risk for hepatitis B, hepatitis C, and HIV in the State of Santa Catarina, Brazil, 1991-2001. The Brazilian Journal of Infectious Diseases 2004; 8(3):236-240.

50. Thomas DL, Cannon RO, Shapiro CN, Hook EW 3rd, Alter MJ, Quinn TC. Hepatitis C, hepatitis B, and human immunodeficiency virus infections among non-intravenous drug-using patients attending clinics for sexually transmitted diseases. J Infect Dis 1994; 169:990-995.

51. Goldberg D, McIntyre PG, Smith R, Appleyard K, Dunlop J, Taylor A, Hutchinson S. Hepatitis $C$ virus among high and low risk pregnant women in Dundee: unlinked anonymous testing. $\mathrm{Br} \mathrm{J}$ Obstet Gynaecol 2001; 108: 365-370.

52. Vandelli C, Renzo F, Romano L, Tisminetzky S, De Palma M, Stroffolini T, Ventura E, Zanetti A. Lack of evidence of sexual transmission of hepatitis $\mathrm{C}$ among monogamous couples: results of a 10-year prospective follow-up study. Am J Gastroenterol. 2004; 99(5): 855-9.

53. Magder, Fix AD, Mikhail NN, Mohamed MK, Abdel-Hamid M, Abdel-Aziz F, Medhat A, Strickland GT. Estimation of the risk of transmission of hepatitis $C$ between spouses in Egypt based on seroprevalence data. International Journal of Epidemiology 2005; 34:160-165.

54. Alary M, Joly JR, Vincelette J, Lavoie R, Turmel B, Remis RS. Lack of evidence of sexual transmission of hepatitis $C$ virus in a prospective cohort study of men who have sex with men. American Journal of Public Health. 2005, 95(3):502-5.

55. Niu MT, Coleman PJ, Alter MJ. Multicenter study of hepatitis C virus infection in chronic hemodialysis patients and staff. Am J Kidney Dis 1993;22:568-573

56. Conlon PJ, Walshe JJ, Smyth EG, McNamara EB, Donohoe J, Carmody M. Lower prevalence of anti-hepatitis $C$ antibody in dialysis and renal transplant patients in Ireland. Irish J Med Sci 1993;162:145-147

57. Medin C, Allander T, Roll M, Jacobson SH, Grillner L. Seroconversion to hepatitis $\mathrm{C}$ virus in dialysis patients: a retrospective and prospective study. Nephron 1993;65:40-45

58. Hardy NM, Sandroni S, Danielson S, Wilson WJ. Antibody to hepatitis $\mathrm{C}$ virus increases with time on hemodialysis. Clin Nephrol 1992;38:44-48

59. Nordenfelt E, Lofgren B, Widell A, Hansson BG, Zhang YY, Hagstam KE, Kurkus J. Hepatitis C virus infection in hemodialysis patients in Southern Sweden: epidemiological, clinical, and diagnostic aspects. J Med Virol 1993;40:266-270

60. Hayashi J, Yoshimura E, Nabeshima A, Kishihara Y, Ikematsu H, Hirata M, Maeda Y, Kashiwagi S. Seroepidemiology of hepatitis C virus infection in hemodialysis patients and the general population in Fukuoka and Okinawa, Japan. J Gastroenterol 1994;29:276-281

61. Qadi AA, Tamim H, Ameen G, Bu-Ali A, Al-Arrayed S, Fawaz NA, Almawi WY. Hepatitis B and Hepatitis $C$ virus prevalence among dialysis patients in Bahrain and Saudi Arabia: a survey by serologic and molecular methods. Am J Infect Control. 2004; 32(8):493-5.

62. Mendez-Sanchez N, Motola-Kuba D, Chavez-Tapia NC, Bahena J, Correa-Rotter R, Uribe M. Prevalence of Hepatitis C virus infection among hemodialysis patients at a tertiary-care hospital in Mexico City, Mexico. Journal of Clinical Microbiology, 2004; 42(9): 43214322.
63. Halfon P, Khiri H, Feryn JM, Sayada C, Chanas M, Ouzan D. Prospective virolocial followup of hepatitis C infection in a haemodialysis unit. J Viral Hepat 1998;5:115-121

64. Fabrizi F, Martin P, Dixit V, Brezina M, Russell J, Conrad A, Schmid P, Gerosa S, Gitnick G. Detection of de novo hepatitis C virus infection by polymerase chain in hemodialysis patients. Am J Nephrol 1999;19:383-388

65. Zampieron A, Jayasekera H, Elseviers M, Lindley E, De Vos JY, Visser R, Harrington M. European study on epidemiology and the management of $\mathrm{HCV}$ in the haemodialysis population-Part 1:centre policy. EDTNA ERCA J. 2004; 30(2):84-90.

66. Angelico M, Tisone G, Rapicetta M, Pisani F, Gandin C, Chionne P, Dettori S, Iaria G, Danese V, Orlando G, Casciani CU. Hepatitis C virus infection in Italian kidney graft recipients. Changing risk factors and hepatitis C virus genotypes. Ital J Gastroenterology Hepatology 1997; 29:448-55.

67. Cheung RC. Epidemiology of hepatitis C virus infection in American Veterans. Am J Gastroenterol 2000; 95:740-747.

68. Dominitz JA, Boyko EJ, Koepsell TD, Heagerty PJ, Maynard C, Sporleder JL, et al. Elevated prevalence of hepatitis C infection in users of United States veteran medical centers. Hepatology 2005; 41(1):88-96.

69. Feldman GM, Sorvillo F, Cole B, Lawrence WA, Mares R. Seroprevalence of hepatitis $\mathrm{C}$ among a juvenile detention population. Journal of Adolescent Health 2004; 25:505-508.

70. Mohsen $\mathrm{AH}$, Trent HCV study group. The epidemiology of hepatitis $C$ in a UK health regional population of 5.12 million. Gut 2001; 48:707-713.

71. Thomson BJ, Finch RG. Hepatitis C virus infection. Clin Microbiol Infect 2005; 11:86-94.

72. Yamada G, Tanaka E, Miura T, Kiyosawa K, Yano M, Matsushima $\mathrm{T}$, Tsubouchi $\mathrm{H}$, Ishikawa $\mathrm{K}$, Kohara $\mathrm{M}$, Hino $\mathrm{K}$, et al. Epidemiology of genotypes of hepatitis $C$ virus in Japanese patients with type $\mathrm{C}$ chronic liver disease; a multi-institution analysis. J Gastroenterol Hepatol 1995; 10:538-545.

73. Okamoto H, Kobata S, Tokita H, Inoue T, Woodfield GD, Holland PV, Al-Knawy BA, Uzunalimoglu O, Miyakawa Y, Mayumi M. A second-generation method of genotyping hepatitis $C$ virus by the polymerase chain reaction with sense and antisense primers deduced from the core gene. J Virol Methods 1996; 57:31-45.

74. Ohno O, Mizokami M, Wu RR, Saleh MG, Ohba K, Orito E, Mukaide M, Williams R, Lau JY. New hepatitis $C$ virus genotyping system that allows for identification of HCV genotypes 1a, 1b, 2a, 2b, 3a, 3b, 4, 5a, and 6a. J Clin Microbiol 1997; 35:201-207.

75. Zusinaite E, Metskula K, Salupere R. Autoantibodies and hepatitis C virus genotypes in chronic hepatitis $\mathrm{C}$ patients in Estonia. World J Gastroenterology 2005; 11(4):488-491.

76. Das BR, Kundu B, Khandapkar R, Sahni S. Geographical distribution of hepatitis $C$ virus genotypes in India. Indian J Pathol Microbiol. 2002; 45: 323-8.

77. Shah HA, Jafri W, Malik I, Prescott L, Simmonds P. Hepatitis C virus genotypes and chronic liver disease in Pakistan. J Gastroenterology Hepatology 1997; 12:758-61.

78. Valliammai T, Thyagarajan SP, Zuckerman AJ, Harrison TJ. Diversity of genotypes of hepatitis $\mathrm{C}$ virus in southern India. J General Virol. 1995; 76(3): 711-16.

79. Osoba AO. Hepatitis C virus genotypes in Saudi Arabia. Saudi Med J. 2002; 23:7-12.

80. Bdour S. Hepatitis C virus infection in Jordanian haemodialyis units, serological diagnosis and genotyping. J Med Microbiol. 2002; 51:700-4.

81. Smuts HE, Kannemeyer J. Genotyping of hepatitis C virus infection in South Africa. J Clin Microbiol. 1995; 33:1679-81.

82. Huy TT, Abe K. Molecular epidemiology of hepatitis B and C virus infections in Asia. Pediatrics International. 2004; 46:223-230.

83. [Internet] CDC: US. Viral Hepatitis C http://www.cdc.gov/ncidod/diseases/hepatitis/c/plan/Prev_Co ntrol.htm

84. Backmund M, Reimer J, Meyer K, Gerlach JT, Zachoval R. Hepatitis $\mathrm{C}$ virus infection and injection drug users: prevention, risk factors, and treatment. Clin Infect Dis. 2005; 40 (Suppl 5):S330-5. 
85. Edlin BR, Kresina TF, Raymond DB, Carden MR, Gourevitch MN, Rich JD, Cheever LW, Cargill VA. Overcoming barriers to prevention, care, and treatment of hepatitis $C$ in illicit drug users. Clin Infect Dis. 2005; 40 (Suppl 5):S276-85. 